\title{
Dr. Zyun Hidaka
}

本会名誉会員元九州大学教授日高醇先生は平成 8 年 （1996） 2 月 28 日午後 11 時 05 分, 福岡市東区香住ヶ丘 3-5-41 のご自宅において心筋梗塞のため満 84 歳の生涯を 閉じられました。嘆んで哀悼の意を表します。3月 1 日には 通夜, 3 月 2 日午後 2 時より積善社福岡斎場において多数 の参列者の下，葬儀がしめやかにとり行われました。

瘦身ながら頑健な先生のご日常から，訃報は全く青天の 霹震であり，奥様によると入浴中の突然の発作によるご逝 去で, 誰にも迷惑をかけず大往生であった由でありました。 この年, 4 月初めに佐賀大学および九州大学において本会 大会およびウイルス病研究会が予定されており，久し振り に先生にお目にかかれることを楽しみにしていた矮で， 悲しみもひとしおであります。

先生は明治 44 年 (1911) 7 月 29 日, 宮崎県佐土原町に生 を受けられ, 昭和 10 年 (1935) 宮崎高等農林学校を卒業さ れ, 続いて昭和 13 年 (1938) 九州帝国大学農学部農学科を ご卒業になり, 同年大蔵省専売局に入局されました。以後, 昭和 39 年 (1964) までの間, 主として秦野たばこ試験場に 勤務され, 病虫部長としてタバコの病害虫研究に数々の成 果を挙げられました。昭和 39 年 3 月には母校九州大学に教 授として迎えられ，同50年（1975）4月 1 日のご定年, 退 官に至る間, 植物病理学研究室を主幸され, 研究および後 進の教育に献身されました。このほか, 山口大学, 鳥取大 学をはじめ鹿児島大学, 琉球大学の非常勤講師として後進 の教育に当たられております。また，ご退官の後は一時期 福岡歯科大学教授として同大学の設立に貢献されました。 社会的には日本学術会議の微生物学, 生物科学研究連絡委 員会委員, 同生物科研究委員会, 微生物分科会委員長, 植 物保護農薬研究連絡委員会委員長等を歴任し, 昭和 47〜 00 年には日本学術会議会員に選出され, 活動されました。さ らに日本電子顕微鏡学会会長 (昭和 37 年度), 日本ウイル 不学会会長 (昭和 42 年度), 日本植物病理学会会長（昭和 46 年度)を歴任し, また昭和 50 年には日本微生物学協会の 設立に尽力され，以後同会の会長を務められました。この ように植物病理学のみならず微生物学全般にわたってその 発展に貢献されております。

先生の植物病理学のご研究の成果は, 100 編以上の論文, 著書, 特許等に示されるように, 数多く多岐にわたり, 限

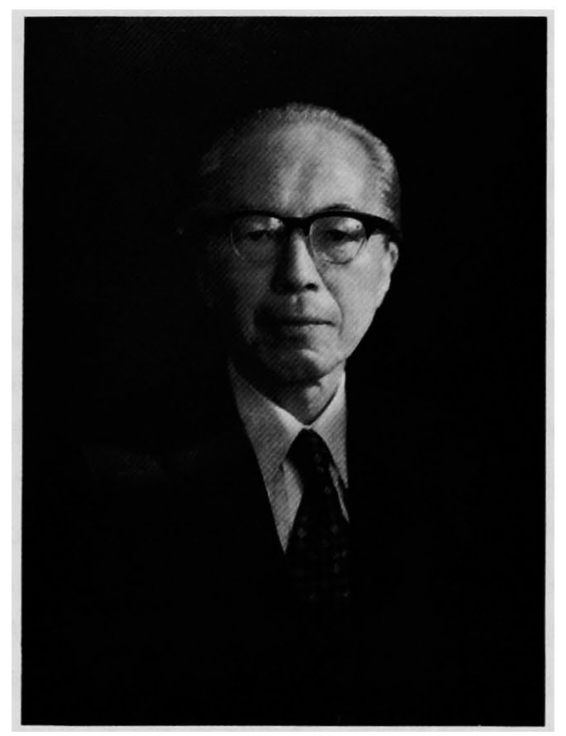

られた紙面で多くを述べることはできないのが残念です が, 日本専売公社在職の 26 年間には特筆すべき成果として 以下の 4 研究があります。（1）クロルピクリンによる土㙋 消毒法の開発に関する研究, (2) タバコわい化病に関する 研究と防除法の確立，（3）タバコにおけるキュウリモザイ ク病の総合防除法の開発, 確立, (4) 抗生物質ストレプト マイシンによる植物細菌病予防法の開発に関する研究。

(1) のクロルピクリンによる土䱋消毒に関する研究で は，それまで倉庫くん蒸に用いられていた同剤の土壌消毒 への適用に着目され, 安全, 確実に土㙵伝染性病害を防除 する技術を初めて開発されました。タバコをはじめコン ニャクなど多くの作物あるいは施設栽培で, 現在でも広く 用いられ，定着した技術となっています。この土壤消毒に 関する精細なご研究は, 昭和 26 年先生の学位論文(九州大 学)となり,またこの技術開発は昭和 29 年日本専売公社総 裁表彰の栄に浴しております。

（2）のわい化病に関する研究では, 本病が昭和 6 年 (1931)頃から広島県など一部地域のタバコに発生し，その 後全国的に重要品種（ブライトエロー）に多発し, 問題と なりました。先生は本病が, タバコ萎黄病の病原菌でもあ る Olpidium brassicaeによって伝搬されるウイルスであ ることを明らかにし，防除法を開発されました。ウイルス の菌類による伝搬は，ほほ同時期にそれぞれ独立に海外の 
レタス big-vein 病でも認められましたが,わい化病の研究 はウイルスの土壌伝染に菌類の関与を示した最初の発見と して，高く評価されています。この成果を中心としたタバ コ病害に関する研究によって, 先生は昭和 34 年 (1959) 日 本植物病理学会賞を受賞されました。

（3）のキュウリモザイク病の総合防除試験は昭和 24 年 (1949)頃から激しい発生を示した本病の病原であるキュウ リモザイクウイルスの基整的研究の成果を基として，総合 防除法を企画, 立案され，全国 4 力所で試験を行い成功を 収めたものであります。その後，慣行的技術として産地に 定着し，大きな成果を挙げました。この防除法によって産 地の衰亡を免れた鹿児島県の一地域では, この防除試験の 記念碑を建立しましたが，このような例は希有のことであ るとして米国の成書（G.B. Lucas, 1965）に写真とともに 紹介されております。本研究も昭和 36 年 (1961) 総裁表彰 の栄誉を受けました。この表彰を記念して先生は夕バコの 葉とアブラムシを模した銅製メダルを作られ共同研究者の 全員に配られました。これは今でも私の手許にあります。

(4) のストレプトマイシンの植物細菌病防除への応用で は, 医薬用の同㘊では高価で農薬用には経済的に不適であ ることから，生産菌の培養滤液の利用に着目されました。 滤液への塩酸塩または硫酸塩の添加が活性低下防止に有効 であることおよび同剤が植物体内に吸収され，移行するこ とを明らかにされました。本郕はヒトマイシンとして実用 に供され，現在でも細菌病の防除刘として用いられていま す。これは抗生物質の農楽への適用の最初の例として評価 の高い業績であります。

このほかのご功績として, 学術の国際交流における貢献 があります。先生は国際微生物学会連合会議の組織委員長 として, 昭和 49 年 (1974) 東京における第一回の同会議を
成功に導かれました。昭和 48 年 (1973) には国際植物病理 学会副会長の要職を務められ, 昭和 63 年 (1988) の第 5 回 国際植物病理学会議（京都）の布石をされました。

上述のようなご業績に対して昭和 50 年（1975）には紫綬 震章を受章され，また，昭和 58 年 (1983) には勲三等旭日 中綬章の栄誉を受けられました。

先生は常に前向きの情熱を学問の発展に注がれ, 堅い信 念の下に率先して行動されました。開発された技術は戦後 の新しい技術を求める農業に良く適合し，乾いた大地に水 が渗みわたるように普及したと言えると思います。これは， 先生の卓越した洞察力, 指導力また組織力によるものであ りましょう。常に農村, 産地をめぐり, 講演会等によって 技術の普及を図られ，また，産地の技術者との意志踈通を 図られたことも印象的でありました。ご多饭の間にも研究 室のセミナーを欠かさず，後進の我々を指導されました。 また, 山や植物を愛された先生は, 研究室の年一回の旅行 も 1 2 泊の山行きとなりました。伊豆半島縦走, 尾瀬, 八 甲田・酸ヶ湯, 立山, 白馬など, 当時としては健脚向きの コースを，地下足袋，脚絆の先生の先導の下に踏破したこ とも慣かしい思い出であります。

先生のご遺志は福岡市在住のヒ口子奥様 (故中田覚五郎, 九大, 東大教授, 植物病理学, ご長女), ご子息操氏(東北 農業試験場, 作物開発部上席研究官, 生物工学) に受け継 がれ，またご指導を受けた多くの後進によって伝えられる ものと信じます。先生は戒名を智昿院醇節日缺居士, 菩提 寺を福岡市博多区中呉服町の本長寺とし, 福岡県宗像郡玄 海町大字多礼の「玄海霊園」に眠っておられます。

ご冥福を心からお祈り申し上げます。 都丸敬一 